\title{
DENTISTRY
}

Novoshytskyy V. E., Mazur I. P.

\section{MANDIBULAR OSTEOMETRIC INDICES IN PATIENTS WITH PERIODONTITIS DEPENDING ON VITAMIN D LEVEL}

Shupyk National Medical Academy of Postgraduate Education, Ukraine

\begin{abstract}
Recent studies have reported a relationship between vitamin D level, bone tissue and periodontitis. The aim of study was to determine mandibular osteometric indices in patients with periodontitis depending on the level of vitamin D. We have examined 95 patients with periodontitis. Patients were divided into 3 groups according to 25 -hydroxyvitamin-D concentration in plasma. All patients were examined to determine vitamin D level and mandibular osteometric indices. Mandibular height in the canine area in patients with vitamin D sufficiency was the lowest and was $27.33(25.15-29.02) \mathrm{mm}$. Mandibular height in patients with vitamin D deficiency and insufficiency was $28.04(25.91-29.78) \mathrm{mm}$ and $29.03(26.70-31.21) \mathrm{mm}$, respectively. Mandibular body height in the canine area in patients with GP and vitamin D deficiency, insufficiency and sufficiency was $16.68(14.95-18.45) \mathrm{mm}, 17.34(15.74-19.42) \mathrm{mm}$ and $15.93(14.65-$ $17.23) \mathrm{mm}$, respectively and alveolar bone height in canine area was $11.55(9.53-12.85) \mathrm{mm}, 11.21(10.00-13.81) \mathrm{mm}$ and $11.21(9.69$ 12.75) $\mathrm{mm}$, respectively. Thus, the increase of mandibular height in patients with periodontitis who had vitamin D deficiency and insufficiency occurred by the increase of mandibular body height.
\end{abstract}

KeyWords: periodontitis, vitamin $\mathrm{D}$, bone tissue, mandible, osteometric indices.

\section{INTRODUCTION}

Vitamin D plays an important role in prevention of many diseases, including rickets, osteoporosis, both types of diabetes mellitus and others [1-4]. Its deficiency and insufficiency are widespread in Ukraine and worldwide [57]. Periodontitis is also widespread throughout the world. It is characterized by inflammation in the periodontal tissues, alveolar bone loss, resulting in the occurrence of tooth mobility and tooth loss. Some studies showed an increase in mandibular body in patients with periodontitis $[8,9]$. In particular, Mazur demonstrated that the height of mandible body increased in an experimental model in rats with periodontitis. This happened as a result of the alveolar bone loss. The incidence of vitamin $D$ deficiency and periodontitis determines the relevance of studying their relationship. Many authors noted the existence of that relationship [10-13].

\section{Corresponding Author:}

Volodymyr Novoshytskyy - Assistant of Professor, Department of Dentistry, Shupyk National Medical Academy of Postgraduate Education, Ukraine, tel.: 093-254-12-08,

Email:nov_vol@mail.ru
In particular, Dietrich et al. showed a negative correlation between 25-hydroxyvitamin-D3 concentration and periodontal disease in men and women aged 50 years (the greater 25-hydroxyvitamin-D3 concentration, the lower the level of clinical attachment loss) [10]. Studying the relationship between 25-hydroxyvitamin-D (25(OH)D) concentration and periodontal disease in women during pregnancy Boggess et al. concluded that periodontal disease in pregnant women was associated with $25(\mathrm{OH}) \mathrm{D}$ levels below 75 nmol/L [12].

\section{PURPOSES, SUBJECTS and METHODS:}

\subsection{Purpose}

The aim of study was to determine mandibular osteometric indices in patients with periodontitis depending on the level of vitamin D.

\subsection{Subjects}

The study involved 95 (60 women (63.2\%) and 35 men $(36.8 \%$, mean age $43.21 \pm 11.77(M \pm S D)$ years $)$ patients with periodontitis who were examined within the period from March 2012 to January 2016. The 
patients were divided into 3 groups according to plasma 25(OH)D concentration. Group 1 included 21 patients with vitamin D sufficiency. Group 2 consisted of 40 patients with vitamin D insufficiency. Group 3 included 34 patients with vitamin $\mathrm{D}$ deficiency. The distribution of patients into the groups depending on the level of vitamin $\mathrm{D}$ is presented in Table 1.

Table 1.

Patients distribution into groups depending on the level of vitamin D (vitamin D level, the number of patients and age of patients in groups)

\begin{tabular}{|l|l|l|l|l|}
\hline Groups & $\begin{array}{l}\text { Number } \\
\text { of } \\
\text { patients, } \\
\mathrm{n}\end{array}$ & $\begin{array}{l}\text { Number } \\
\text { of } \\
\text { patients, } \\
\%\end{array}$ & $\begin{array}{l}\text { Age } \\
\text { Me (IQR) }\end{array}$ & $\begin{array}{l}\text { Vitamin } \\
\text { level } \\
(\mathrm{ng} / \mathrm{mL}) \\
\text { Me (IQR) }\end{array}$ \\
\hline $\begin{array}{l}\text { Group 1 } \\
\text { (vitamin } \\
\text { sufficiency) }\end{array}$ & 21 & 22.1 & $\begin{array}{l}42.00 \\
(31.50-\end{array}$ & $\begin{array}{l}35.90 \\
(32.43- \\
40.45)\end{array}$ \\
\hline $\begin{array}{l}\text { Group 2 } \\
\text { (vitamin D } \\
\text { insufficiency) }\end{array}$ & 40 & 42.1 & $\begin{array}{l}\text { (32.00) } \\
(33.75-\end{array}$ & $\begin{array}{l}23.52 \\
(21.33-\end{array}$ \\
\hline $\begin{array}{l}\text { Group 3 } \\
\text { (vitamin D } \\
\text { deficiency) }\end{array}$ & 34 & 35.8 & $\begin{array}{l}(31.75- \\
26.17)\end{array}$ \\
\hline
\end{tabular}

\subsection{Methods}

Diagnosis of periodontitis was established according to the Danilevsky classification (1998). [14]. Clinical examination methods included the presence of gums bleeding, periodontal pockets and clinical attachment loss (periodontal probe using) determination. Other means included radiological methods of examination (panoramic radiographs) and osteometric methods.

To determine the relationship between 25(OH)D level and compensatory mechanisms in mandible the study implied determination of mandibular height, mandibular body height, alveolar bone height in canine area and mandibular cortical width [15]. Mandibular body height was defined as the length of the perpendicular lowered from the canine root apex to the bottom of the mandibular cortical plate. Mandibular body was measured on both sides of the mandible, and their average value was calculated statistically. The height of the mandible was determined in two parts of the mandible: in the canine area and in the mental foramen area. Mandibular height in the canine areas was defined as the length of the perpendicular lowered from the top of mandibular alveolar bone in canine areas to the bottom of the mandibular cortical plate. Mandibular height in canine area was measured on both sides of the mandible, and their average value was calculated statistically. Mandibular height in mental foramen area was defined as the length of the perpendicular lowered from the top of mandibular alveolar bone to the bottom of the mandibular cortical plate through the middle of mental foramen. Mandibular height in mental foramen area was measured on both sides of the mandible, and their average value was calculated statistically. Mandibular alveolar bone height in canine area was defined as the length of the perpendicular lowered from the top of mandibular alveolar bone to the canine root apex. Mandibular alveolar bone height was measured on both sides of the mandible, and their average value was calculated statistically. Mandibular cortical width was defined as the length of the perpendicular lowered from the top of mandibular cortical plate to the bottom of mandibular cortical plate below the mental foramen. Mandibular cortical width was measured on both sides of the mandible, and their average value was calculated statistically. The methods for measuring of mandibular height in canine area and in mental foramen area, mandibular body height, alveolar bone height in canine area and mandibular cortical width are presented in Figure 1.

To verify the diagnosis of vitamin D deficiency and insufficiency we used classification (2011) adopted by the International Institute of Medicine and Endocrine Society Clinical Practice Guideline. According to this classification vitamin $D$ deficiency was observed when vitamin $D$ level was less than $20 \mathrm{ng} / \mathrm{mL}$, insufficiency when vitamin $D$ level was from 20 to $30 \mathrm{ng} / \mathrm{mL}$ and sufficiency when vitamin $D$ level was from 30 to $50 \mathrm{ng} / \mathrm{mL}$ [16]. 
foramen area, mandibular body height and alveolar bone

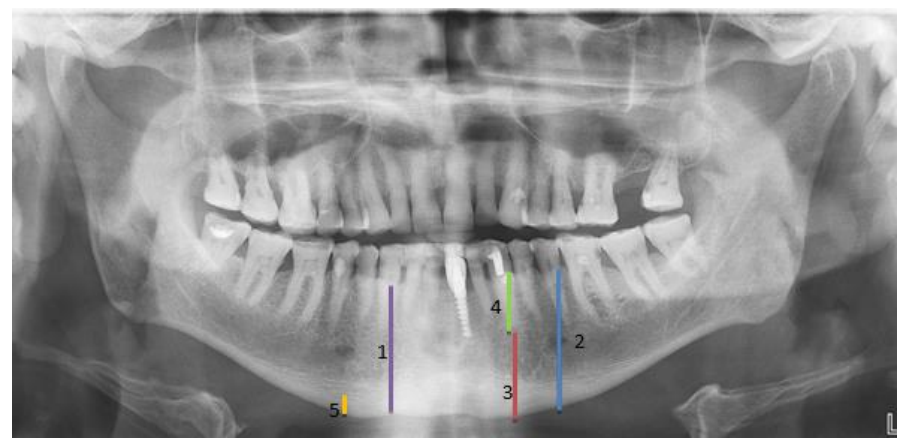
height in canine area) in patients with periodontitis depending on the level of vitamin $D$ and their statistical comparison are presented in Table 2.

Table 2.

Values of osteometric indices (mandibular height in canine area and in mental foramen area, mandibular body height and alveolar bone height in canine area) in patients with periodontitis depending on the level of vitamin D

Figure 1. Methods for measuring of mandibular height in canine area and in mental foramen area, mandibular body height, alveolar bone height and mandibular cortical width (1 - mandible height in canine areas; 2 - mandibular height in mental foramen area; 3 - mandibular body height; 4 - alveolar bone height in canine area; 5 - mandibular cortical width)

Statistical analysis was performed using statistical software package (SPSS version 20).

\section{Conflict of interests}

There is no conflict of interests.

\section{RESULTS AND DISCUSSION}

To determine mandibular osteometric indices in patients with periodontitis depending on the level of vitamin $D$ we measured mandibular height in canine area and in mental foramen area, mandibular body height and alveolar bone height in canine area. The results of the study demonstrated that the lowest mandibular height in the canine area was observed in patients with periodontitis and vitamin D sufficiency. Mandibular height in the canine area in patients with vitamin $D$ insufficiency was significantly higher than in patients with vitamin $D$ sufficiency $(p=0.054)$. In the study of mandibular body height the patients with vitamin $D$ sufficiency were found to have the lowest mandibular body height in the canine area and it constituted $15.93(14.65-17.23) \mathrm{mm}$. Mandibular body height in the canine area in patients with vitamin $D$ insufficiency was significantly higher than in patients with vitamin $D$ sufficiency $(p=0.049)$. There was no significant difference between alveolar bone height in canine area in patients with periodontitis depending on the level of vitamin $D(p>0.05)$. The values of osteometric indices (mandibular height in canine area and in mental

\begin{tabular}{|c|c|c|c|c|c|}
\hline \multirow{3}{*}{ Index } & \multicolumn{3}{|c|}{ Vitamin D level } & \multicolumn{2}{|c|}{ Comparison } \\
\hline & \multirow{2}{*}{\begin{tabular}{|c|} 
Sufficiency \\
Me (IQR)
\end{tabular}} & \multirow{2}{*}{\begin{tabular}{|l} 
Insufficiency \\
Me (IQR)
\end{tabular}} & \multirow{2}{*}{$\begin{array}{l}\text { Deficiency } \\
\text { Me (IQR) }\end{array}$} & \multirow{2}{*}{ Gp. } & \multirow{2}{*}{$\mathrm{p}$} \\
\hline & & & & & \\
\hline \multirow{3}{*}{$\begin{array}{l}\text { Mandibular } \\
\text { height in ca- } \\
\text { nine area, mm }\end{array}$} & \multirow{3}{*}{$\begin{array}{l}27.33 \\
(25.15-29.02)\end{array}$} & \multirow{3}{*}{$\begin{array}{l}29.03 \\
(26.70-31.21)\end{array}$} & \multirow{3}{*}{$\begin{array}{l}28.04 \\
(25.91-29.78)\end{array}$} & $1-2$ & 0.054 \\
\hline & & & & $1-3$ & 0.319 \\
\hline & & & & $2-3$ & 0.222 \\
\hline \multirow{3}{*}{$\begin{array}{l}\text { Mandibular } \\
\text { body height, } \\
\mathrm{mm}\end{array}$} & \multirow{3}{*}{$\begin{array}{l}15.93 \\
(14.65-17.23)\end{array}$} & \multirow{3}{*}{$\begin{array}{l}17.34 \\
(15.74-19.42)\end{array}$} & \multirow{3}{*}{$\begin{array}{l}16.68 \\
(14.95-18.45)\end{array}$} & $1-2$ & $0.049^{*}$ \\
\hline & & & & $1-3$ & 0.350 \\
\hline & & & & $2-3$ & 0.269 \\
\hline \multirow{3}{*}{$\begin{array}{l}\text { Alveolar bone } \\
\text { height in ca- } \\
\text { nine area, } \mathrm{mm}\end{array}$} & \multirow{3}{*}{$\begin{array}{l}11.21 \\
(9.69-12.75)\end{array}$} & \multirow{3}{*}{\begin{tabular}{|l}
11.21 \\
$(10.00-13.81)$
\end{tabular}} & \multirow{3}{*}{$\begin{array}{l}11.55 \\
(9.53-12.85)\end{array}$} & $1-2$ & 0.635 \\
\hline & & & & $1-3$ & 0.609 \\
\hline & & & & $2-3$ & 0.883 \\
\hline
\end{tabular}

The results of the study of mandibular height in mental foramen area demonstrated that the lowest mandibular height in mental foramen area was observed in patients with periodontitis that have vitamin D sufficiency and was 26.03 $(23,65-27,68) \mathrm{mm}$. In patients with vitamin $D$ deficiency and insufficiency mandibular height in mental foramen area was 28.03(25.90-31.17) $\mathrm{mm}$ and 26.56(24.4528.38) $\mathrm{mm}$ respectively. Mandibular height in mental foramen area in patients with vitamin $D$ insufficiency was significantly higher than in patients with vitamin $D$ sufficiency $(p=0.010)$. There was no significant difference between mandibular cortical width in patients with periodontitis depending on the level of vitamin $D(p>$ 0.05). The values of mandibular height in mental foramen area and mandibular cortical width in patients with periodontitis depending on the level of vitamin $\mathrm{D}$ and their statistical comparison are presented in Table 3.

Therefore the results of the study showed that mandibular height in mental foramen area and in canine area were the lowest in patients with periodontitis that have vitamin $D$ sufficiency. 
Table 3.

Values of osteometric indices (mandibular height in canine area and in mental foramen area, mandibular body height and alveolar bone height in canine area) in patients with periodontitis depending on the level of vitamin D

\begin{tabular}{|c|c|c|c|c|c|}
\hline \multirow{3}{*}{ Index } & \multicolumn{3}{|c|}{ Vitamin D level } & \multicolumn{2}{|c|}{ Comparison } \\
\hline & Sufficiency & \multirow{2}{*}{ Me (IQR) } & \multirow{2}{*}{\begin{tabular}{|l} 
Deficiency \\
Me (IQR)
\end{tabular}} & \multirow{2}{*}{ Gp. } & \multirow[b]{2}{*}{$\mathrm{p}$} \\
\hline & Me (IQR) & & & & \\
\hline \multirow{3}{*}{$\begin{array}{l}\text { Mandibular } \\
\text { height in } \\
\text { mental fora- } \\
\text { men area, } \mathrm{mm}\end{array}$} & \multirow{3}{*}{$\begin{array}{r}26.03 \\
(23.65- \\
27.68)\end{array}$} & \multirow{3}{*}{$\begin{array}{r}28.03 \\
(25.90- \\
31.17)\end{array}$} & \multirow{3}{*}{$\begin{array}{l}26.56 \\
(24.45- \\
28.38)\end{array}$} & $1-2$ & $0.010^{\prime}$ \\
\hline & & & & $1-3$ & 0.188 \\
\hline & & & & $2-3$ & 0.175 \\
\hline \multirow{3}{*}{$\begin{array}{l}\text { Mandibular } \\
\text { cortical width, } \\
\mathrm{mm}\end{array}$} & \multirow{3}{*}{$\begin{array}{c}3.64 \\
(3.16-4.16)\end{array}$} & \multirow{3}{*}{$\begin{array}{c}3.44 \\
(2.87-4.18)\end{array}$} & \multirow{3}{*}{$\begin{array}{c}3.83 \\
(3.07-4.30)\end{array}$} & $1-2$ & 0.403 \\
\hline & & & & $1-3$ & 0.749 \\
\hline & & & & $2-3$ & 0.270 \\
\hline
\end{tabular}

* Significant differences between the groups

Increasing of mandibular height in patients with periodontitis that had vitamin $D$ deficiency and insufficiency was due to a compensatory increase of mandibular body height. This increase might occur as a compensatory mechanism of the mandible to chewing that load by the loss of alveolar bone of mandible. This can be due to the increase of bone metabolic activity that occurs on the background of vitamin $D$ deficiency and insufficiency [17].

\section{CONCLUSIONS}

1. The relationship between vitamin $D$ level and mandibular osteometric indices in patients with periodontitis exists.

2. The lowest mandibular height in mental foramen area and in canine area was observed in patients with periodontitis that occurs on the background of vitamin D sufficiency.

3. The increase of mandibular height in patients with periodontitis who had vitamin $D$ deficiency and insufficiency occurred by the increase of mandibular body height.

\section{REFERENCES}

1. Stein, S.H., Tipton, D.A. (2011) Vitamin D and its impact on oral health - an update J Tenn Dent Assoc, 91(2), 30-3;

2. Ponsonby, A., Lucas, R., van der Mei, I (2005)
UVR, vitamin D and three autoimmune diseases-multiple sclerosis, type 1 diabetes, rheumatoid arthritis. Photochem. Photobiol, 81, 1267-1275.

3. Harris, S.S. (2005) Vitamin D in type 1 diabetes prevention J. Nutr., 135, 323-325.

4. Pittas, A.G., Lau, J., Hu, F.B., Dawson-Hughes, B. (2007) The role of vitamin D and calcium in type 2 diabetes. A systematic review and meta-analysis. J. Clin. Endocrinol. Metab., 92, 2017-2029.

5. Povoroznnyuk, V.V., Balatska, N. I. (2012) Deficyt vitamin $D$ u naselennia Ukrainy ta factory ryzyku jogo rozvytku [Vitamin D deficiency in Ukrainian population and risk factors for its development]. Pain. Joints. Spine, 4 (08),

6. Lopes, V.M., Lopes, J.R., Brasileiro, J.P., Oliveira, I., Lacerda, R.P., Andrade, M.R., ..... Motta, L.A. (2016) Highly prevalence of vitamin D deficiency among Brazilian women of reproductive age. Arch Endocrinol Metab., 10. DOI: 10.1590/2359-3997000000216

7. Larijani, B., Hossein-Nezhad, A., Feizabad, E., Maghbooli, Z., Adibi, H., Ramezani, M., Taheri, E. (2016) Vitamin $D$ deficiency, bone turnover markers and causative factors among adolescents: a cross-sectional study. J Diabetes Metab Disord. 12, 15-46.

8. Mazur, I. P. (2006) Kliniko-patohenetychni osoblyvosti perebihu zahvoruvan parodonta pry porushenni systemnogo kistkovogo metabolism ta ih korekcia [Clinicopathogenetic peculiarities of periodontal diseases progress during systemic bony metabolism violation and its correction]. D. Dissertation, Shupyk National Medical Academy of Postgraduate Education, Kyiv.

9. Zhurochko, E. I. (2011) Eksperementalne doslidgennia dystrofichno-dystruktyvnyh procesiv $\mathrm{V}$ tkanynah parodontu bilyh shchuriv reproductyvnoho viku za danymy osteometrii [Experimental research into the dystrophic and destructible processes in the peridental tissues of white rats of reproductive age based on osteometry data] Visnyk stomatologiy., 1, 2-9.

10. Dietrich, T., Joshipura, K.J., Dawson-Hughes, B. (2004) Association between serum concentrations of 25hydroxyvitamin D3 and periodontal disease in the US 
population. Bischoff-Ferrari Am J Clin Nutr., 80(1), 108-

113.

11. Amano Y, Komiyama K, Makishima M. (2009) Vitamin $D$ and periodontal disease. J Oral Sci. 51(1), 11-20. 12. Boggess, K.A., Espinola, J.A., Moss, K., Beck, J., Offenbacher, S., Camargo, C.A. Jr. (2011) Vitamin D status and periodontal disease among pregnant women. J Periodontol., 82(2), 195-200

13. Garcia, M.N., Hildebolt, C.F., Miley, D.D., Dixon, D.A., Couture, R.A., Spearie, C.L., .... Civitelli, R. (2011) One-year effects of vitamin $D$ and calcium supplementation on chronic periodontitis. J Periodontol., 82(1), 25-32.

14. Danylevskyi, N. F., Borysenko, A. V. (2011) Zabolevania parodonta [Periodontal disease]. K.: Zdorovia 15. Mazur, I. P., Makarenko, V. N. (2007) Vozrastobuslovlennye rentgenomorfometricheskie izmenenia nizhnej chelusti $u$ zhenshchin $s$ generalisovannym parodontitom (kliniko-rentgenologicheskoe isledovanie) [Age-caused mandibular morphometric changes in women with generalized periodontitis (clinical and radiological studies)]. Sovremennaia Stomatoloia [Modern dentistry], 4, 56-60.

16. Holick, M.F., Binkley, N.C., Bischoff-Ferrari, H.A., Gordon, CM., Hanley, D.A., Heaney, R.P., ... Weaver, C.M. (2011) Evaluation, Treatment, and Prevention of Vitamin D Deficiency: an Endocrine Society Clinical Practice Guideline. J. Clin. Endocrinol. Metab., 96 (7), 1911-1930.

17. Mazur, I.P., Povoroznnyuk, V.V., Novoshytskyy, V.E. (2016) Osoblyvosti kliniko-rentgenolohichnogo perebigy generalisovanogo parodontytu u pacientiv molodoho viku $v$ zaleshnosti vid rivniz vitamin D [Features of clinical and radiological course of chronic periodontitis in young adult patients depending on the level of vitamin D]. Problems of osteology, 2, 25-29.

Received: 23-Dec. - 2016

Accepted: 20-Mar. - 2017 